\title{
OTÁVIO VELHO: TRAJETÓRIA E PERCURSO ACADÊMICO
}

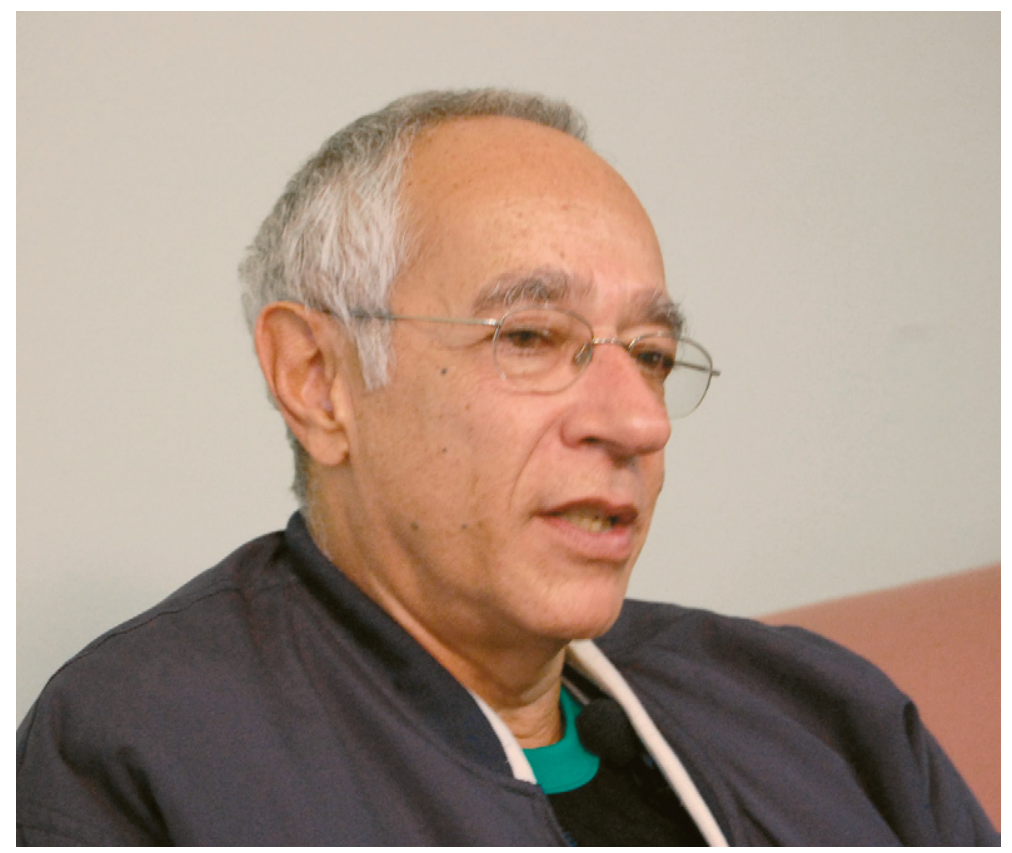

Carlos Steil: Aqui estamos, os professores Sérgio Teixeira, Bernardo Lewgoy, a professora Cornelia Eckert e eu para uma conversa franca e aberta que acontece na sua passagem por Porto Alegre, a convite do PPGAS/UFRGS [Programa de Pós-Graduação em Antropologia Social da Universidade Federal do Rio Grande do Sul], na comemoração dos seus 35 anos de existência. Ontem à tarde [6 de agosto de 2009], ouvimos sua conferência. Hoje, queremos registrar, nesta entrevista para Horizontes Antropológicos, suas considerações sobre a antropologia no Brasil e sua trajetória pessoal como um dos seus principais intelectuais. 
Otávio Velho: Antes de mais nada, agradeço a oportunidade de estar aqui com vocês. Como vocês sabem, tenho uma ligação muito antiga com a antropologia dessa universidade. E é sempre um prazer estar com amigos. Amigos de muito tempo desta universidade e também um ex-aluno: Carlos Steil. Vou falar de uma maneira solta, embora seja difícil de antemão saber o que possa interessar.

Carlos Steil: Para iniciar, você poderia falar um pouco da sua vida, do ambiente familiar em que você cresceu e de como chegou à antropologia.

Otávio Velho: Eu sou de uma família de militares tanto do lado da minha mãe quanto do meu pai. O meu avô materno chegou a general e os meus tios eram quase todos militares. Meu avô, por parte de mãe, era natural do Maranhão e a minha avó era do Rio Grande do Sul, da cidade de Rio Grande, da família Assunção. Aliás, até hoje não conheço a cidade de Rio Grande, gostaria de conhecê-la. Tenho, portanto, uma origem bem brasileira e bem polar, do Maranhão ao Rio Grande do Sul. Por outro lado, meu pai era filho único de imigrantes. Meu avô era português e minha avó uma judia ucraniana. Uma mistura interessante. Meu pai acabou indo para o exército e casou-se com minha mãe, que era de uma família de militares. Uma das consequências de ter vivido numa família militar foi a circulação. Nasci em São Paulo, em 1941, mas vivi lá muito pouco tempo. Era o período da Segunda Guerra. Meu pai foi servir no Nordeste, primeiramente em Fernando de Noronha e depois em Recife. Nessa época, havia uma ideia de que o Nordeste poderia ser invadido por tropas alemãs, vindas do norte da África. Há um episódio, uma curiosidade anedótica, que gostaria de relatar. Quando meu pai estava em Recife, minha mãe e eu ficamos em São Paulo. O plano era nos encontrarmos com ele e mudarmos para Recife. Íamos embarcar num navio, em Santos, que ia para Recife. Na véspera do embarque eu adoeci e nós não embarcamos. O navio foi torpedeado. Então, eu brinco com o Gilberto, meu irmão: "Olha eu salvei a sua vida, você não teria aparecido no mundo se não fosse essa minha doença que impediu que estivéssemos no navio torpedeado." Esse episódio da minha infância já mostra o meu esforço de guerra.

Carlos Steil: E a antropologia agradece. 
Otávio Velho: Sou o filho mais velho. E, há essa curiosidade, o fato de sermos dois irmãos antropólogos que trabalharam a maior parte de suas vidas na mesma instituição. O Gilberto é três anos e meio mais novo do que eu. Fomos criados, basicamente, no Rio, com exceção de três anos, dos sete aos dez anos de idade no meu caso, que moramos nos Estados Unidos. Esses três anos foram muito significativos para mim. Fomos para lá por razões da profissão do meu pai. Ele foi ser professor de português na academia militar de West Point. Talvez tenha sido uma experiência significativa do ponto de vista de um futuro antropólogo, essa experiência intercultural, numa época em que o contato com os Estados Unidos era muito menos corriqueiro do que hoje.

Carlos Steil: Uma pergunta, tentando juntar o elo. Então, você acabou não indo para Recife?

Otávio Velho: De São Paulo fomos para o Rio. Alguns anos depois retornamos a São Paulo, mas por pouco tempo. Então, houve esse convite do próprio exército para o meu pai. Os cadetes, nos Estados Unidos, deviam optar por uma língua estrangeira. E uma das opções era o português. Foi uma experiência forte. Cheguei a esquecer o português. Quando eu retornei para o Brasil eu praticamente só falava o inglês, e tive que reaprender o português. Às vezes acho que tenho um certo jeito de falar que é de quem reaprendeu a língua. Minha formação de primeiro grau foi em escola pública. Sou do tempo que no Brasil a escola pública era frequentada pela classe média. Uma curiosidade é que morávamos no Grajaú, no Rio de Janeiro, na Zona Norte. Depois nos transferimos para Copacabana e lá, ainda na escola pública, fui colega de turma de uma outra futura antropóloga, a Mariza Peirano. Depois fui para o colégio militar, o que era natural, pelo fato de eu ser filho de militar. Fiquei no colégio militar no período do curso de admissão, do ginásio e do secundário. Foram oito anos de colégio militar. Durante uma parte considerável desse tempo, a minha intenção era seguir a carreira militar. Mas o fato de ficar oito anos no colégio militar, de certa maneira, preencheu minha cota de vida militar. Assim, acabei não indo para a academia militar. Estávamos no governo Juscelino e uma outra profissão que aparecia com certo prestígio e interesse para os jovens da época era a engenharia. Pensei em prestar vestibular para engenharia, mas achei que não estava preparado, que deveria estudar mais um ano para me preparar para o vestibular. Nesse ínterim, soube da existência de 
um curso de sociologia na PUC-RJ [Pontifícia Universidade Católica do Rio de Janeiro]. Então, meio para me enganar e para enganar a família, eu pensei: "Já que eu vou ficar um ano me preparando para engenharia, para não ficar totalmente parado, por que não entro para esse curso?" Fui para esse curso, na PUC-RJ, em 1961, e acabei ficando por aí mesmo.

Carlos Steil: Ainda sobre sua trajetória pessoal, talvez você pudesse falar da influência do seu pai, como intelectual, nas suas escolhas.

Otávio Velho: É difícil para a gente mesmo avaliar, mas acho que é significativo o fato de eu e o Gilberto termos escolhido a antropologia. Certamente tem a ver com o nosso pai. Quem não tem muita familiaridade com o meio militar, talvez tenha dificuldade em imaginar um militar intelectual, mas, na verdade, esse é um dos tipos possíveis de militar. Um oficial do exército, que se destacava como um tipo intelectual. Certamente o pai fazia parte de uma ala, digamos assim, intelectualizada do exército. Isso teve uma influência muito grande sobre nós. A biblioteca do nosso pai era importante para nós como referência. Nessa biblioteca havia livros de ciências sociais. Depois que o meu pai retornou dos Estados Unidos, ele começou a fazer traduções do inglês para o português. Foi tradutor da revista Seleções do Reader's Digest e para editoras importantes na época, sobretudo para Zahar Editores, tendo criado, inclusive, uma relação de amizade com o editor Jorge Zahar que passou para os filhos. Também traduziu para a editora Civilização Brasileira. Lembro que o primeiro livro que o meu pai traduziu eu fiquei muito interessado por se tratar de um manual de sociologia de Rodney e Mayer, para a editora Zahar. Se não me engano, foi o primeiro livro da editora Zahar. Portanto, vocês podem ver que a sociologia estava realmente entrando em minha casa. Meu pai era um tradutor que se envolvia muito com o trabalho que estava fazendo. Costumava fazer muitas notas de tradutor. Ele traduziu, depois, outros livros de ciências sociais, mas sobretudo livros de psicanálise. Ele foi o principal tradutor para o português dos livros de Erich Fromm, mas também traduziu outros autores, como Karen Horney. Ele traduziu um outro livro bastante significativo, as memórias do Raymond Aron que, salvo um engano meu, foi o único que ele traduziu do francês. Meu pai também se chamava Octavio, mas com a diferença que o nome dele era com "c" e eu tenho outro nome que é Guilherme, Otávio Guilherme. Para não me confundirem com ele eu, nos meus primeiros 
trabalhos, assinava Otávio Guilherme Velho. Depois do falecimento dele eu passei a assinar meus trabalhos como Otávio Velho. Certamente ele foi uma influência muito significativa tanto para mim quanto para o Gilberto.

Carlos Steil: Gostaria que você retomasse o relato de sua trajetória nas ciências sociais, destacando os primeiros anos da institucionalização dessa área do conhecimento no Rio de Janeiro.

Otávio Velho: A Escola de Sociologia e Política da PUC-RJ era, na época, um dos centros pioneiros de estudos de ciências sociais no Brasil. Foi fundada pelo meu primeiro professor de sociologia, o padre Fernando Bastos d'Ávila, que hoje é membro da Academia Brasileira de Letras. Essa escola reuniu várias pessoas que depois prosseguiram na carreira como cientistas sociais, embora ela não pretendesse formar apenas sociólogos. Ela se apresentava também como uma espécie de vestibular para quem pretendia fazer o Instituto Rio Branco. Eu me lembro que por algum tempo eu cogitei essa possibilidade de fazer o exame para o Itamaraty. Chegamos a ter grupos de estudos de preparação para o Itamaraty. Da minha turma, gostaria de mencionar o Moacir Palmeira como alguém com quem convivo desde o começo da década de 1960. Fomos colegas de turma na PUC-RJ e depois nos reencontramos no Museu Nacional. Não por acaso, estamos trabalhando juntos desde aquela época. Outra pessoa dessa época, que não foi para o Museu Nacional, embora tenha feito pós-graduação lá, é o Luiz Antonio Machado da Silva, que hoje está trabalhando no IFCS [Instituto de Filosofia e Ciências Sociais da Universidade Federal do Rio de Janeiro]. Esses foram colegas de turma, mas, fora eles, posso citar outras pessoas com quem depois eu tive laços importantes e que também foram meus contemporâneos como, por exemplo, a Lygia Sigaud, que estava a duas turmas atrás de nós. Então, a Escola de Sociologia e Política da PUC foi significativa e, quando se iniciou a pós-graduação do Museu Nacional, várias pessoas que fizeram graduação na PUC foram para lá. Um pouco mais modernos do que nós - eu, Moacir e Lygia - posso citar outras pessoas que foram da Escola de Sociologia e Política da PUC-RJ para o museu, como o José Sergio Leite Lopes, o Afrânio Garcia Junior e o Alfredo Wagner Berno de Almeida. Os dois primeiros depois se tornaram professores comigo no PPGAS. Mais tarde, com o sistema departamental, a escola terminou. Hoje não existe mais a escola, mas existem os departamentos que surgiram dela. 
Carlos Steil: Havia outros centros de estudo de ciências sociais nessa época no Rio de Janeiro?

Otávio Velho: Havia também o curso de Ciências Sociais, na Universidade do Brasil, que depois se tornou a Universidade Federal do Rio de Janeiro. Mas, com certeza, a Escola de Sociologia e Política da PUC foi muito importante. Para mim, o início da antropologia está lá, embora tenha surgido de certa maneira por acaso. Não havia imaginado preferencialmente a antropologia. O mais natural, naquele contexto da época, era a sociologia, mas eu tive como professor o Manuel Diegues Junior, que me convidou para ser seu assistente na Escola de Serviço Social da PUC-RJ. O Diegues é uma figura importante nas ciências sociais por sua obra e porque dirigia o Centro Latino-Americano de Pesquisas em Ciências Sociais, que era um órgão da Unesco que tinha sede no Rio. Era um centro de referência para as ciências sociais na América Latina, o que mostra que os nossos laços com a América Latina, em termos de ciências sociais, já foram fortes no seu início, depois se afrouxaram e, hoje, talvez, tenham se estreitado de novo. Então, acabei trabalhando como auxiliar de pesquisa no Centro Latino-Americano, como assistente do Diegues, em antropologia. Não havia imaginado isso, mas aí, é claro, que eu resolvi me aprofundar em antropologia. Descobri o livro O índio e o mundo dos brancos, de Roberto Cardoso de Oliveira, que eu não conhecia pessoalmente, mas eu li e gostei muito. O Roberto frequentava o Centro Latino-Americano e eu acabei abordando-o, no centro, para conversarmos e, dessa conversa com ele, surgiu o convite para eu ir para o Museu Nacional, como auxiliar de pesquisa dele, antes do início do Programa de Pós-Graduação. O Programa teve início em agosto de 1968, mas, desde o final de 1966, eu já estava lá, como auxiliar de pesquisa do Roberto. De certa maneira, participei um pouco como auxiliar nas discussões preparatórias da constituição do Programa, sobretudo nas discussões com a Fundação Ford. Eu tinha facilidade com o inglês, então ajudei um pouco, inclusive como tradutor e mediador nas discussões iniciais. Afinal, estive lá desde a pré-história do Programa. Depois que se formou a primeira turma, como já estava trabalhando e fazendo pesquisa antes, pude defender a dissertação de mestrado rapidamente. Assim, tendo entrado no mestrado em agosto de 1968, em começo de 1970 eu já estava defendendo a dissertação. Então, eu gosto de brincar com os alunos hoje, quando reclamam de ter que fazer o mestrado rápido, dizendo que naquela época eu já fiz bem rápido. É 
claro que eu tinha uma vantagem inicial, pois já estava com material de campo acumulado, inclusive havia ido a campo como auxiliar de pesquisa do Roque Laraia, na região do Tocantins paraense. Enfim, acabei sendo o primeiro mestre formado pelo Programa de Pós-Graduação do Museu Nacional.

Carlos Steil: Como se deu essa inversão em sua carreira que transforma um interesse secundário em prioridade?

Otávio Velho: Acho que, na verdade, estava enganando a mim mesmo, e não só a minha família, quando falava que iria fazer engenharia. A preocupação da família era o que eu iria fazer como sociólogo, porque era insólita a possibilidade de alguém se tornar um profissional como cientista social. Isso era visto com uma certa suspeição por parte das famílias. E com uma certa razão. Por isso mesmo, desde o começo, ainda como estudante, acabei me tornando um militante da causa da profissão de cientista social. Nesse sentido, uma experiência importante foi a participação no movimento estudantil. Uma virada muito grande na minha vida pessoal, uma vez que eu vinha de um colégio militar e de uma família de militares. Meu pai, politicamente, era uma pessoa que se identificava com a UDN [União Democrática Nacional] e os mais velhos sabem o que isso significa.

Carlos Steil: O que significou a sua entrada na PUC, vindo de um colégio militar?

Otávio Velho: A entrada na PUC-RJ foi uma abertura de horizontes. Primeiro para o sexo feminino, porque no colégio militar só havia homens. Foi, assim, a minha primeira experiência de convivência próxima com meninas como colegas. Depois, a possibilidade de participar do movimento estudantil foi muito importante. Entro na PUC-RJ em 1961, numa época em que a PUC-RJ era um centro de elaboração política e intelectual. O presidente do DCE [Diretório Central dos Estudantes] era o Aldo Arantes, que depois se tornou presidente da UNE e já foi deputado federal. Havia, na época, uma efervescência política que, no caso da PUC-RJ, acabou dando origem à AP [Ação Popular], que foi um movimento político significativo de esquerda no país, que surgiu especialmente da JUC [Juventude Universitária Católica]. Diria que os dois centros que permitiram a formação da AP foram Belo Horizonte e 
o Rio de Janeiro. Nunca fui membro da AP, mas cito isso para dar uma ideia do caldeirão em que fervia o movimento estudantil. Enfim, o meu período de estudante de graduação foi uma época política muito significativa no Brasil.

Carlos Steil: Como você começa a participar do movimento político?

Otávio Velho: O meu batismo político foi na renúncia do Jânio, com a luta pela posse do Jango. Essa foi realmente a primeira vez que eu tive uma participação política. Acho que a experiência no movimento estudantil foi um grande aprendizado que não estava, de maneira nenhuma, desassociado da minha formação como cientista social. Assim, acabei sendo eleito, aqui em Porto Alegre, em 1963, presidente da Executiva Nacional de Estudantes de Sociologia e Ciências Sociais. Fui o segundo presidente. O primeiro foi Bolívar Lamounier, cientista político mineiro, hoje radicado em São Paulo. E, como presidente da Executiva, passei a ser membro do Conselho da UNE [União Nacional dos Estudantes] no período crucial de 1963 e 1964, até o golpe militar. Essa participação na cúpula do movimento estudantil nesse período foi realmente uma vivência muito forte.

Carlos Steil: Você estava ligado a algum partido na época?

Otávio Velho: No movimento estudantil eu era do chamado grupo dos independentes. Embora não tivesse uma filiação partidária, estava muito próximo do pessoal da JUC e depois da AP, que era o grupo hegemônico na PUC, embora houvesse também pessoas ligadas ao PCB [Partido Comunista Brasileiro]. Ainda que minoritário, o PCB era uma presença importante na PUC e no movimento estudantil como um todo. Assim, como presidente da Executiva de Ciências Sociais e membro do Conselho da UNE, fui obrigado a dar um passo a mais em termos assim, organizacionais. Na verdade, se você não estivesse articulado com algum grupo político você ficava por fora do que estava acontecendo e não tinha possibilidade de participar devidamente. Foi assim que passei a me reunir, embora não fazendo parte formalmente, com o pessoal do PCB, no período de 1963 e 1964. Ao frequentar as reuniões do Partido Comunista, mesmo não sendo formalmente membro, tive a oportunidade, por exemplo, nas vésperas do golpe militar, de participar de uma reunião com o Prestes. Conhecer o velho Prestes - para um jovem como eu [na época, de esquerda] - foi muito emocionante. 
Carlos Steil: Quando você se torna membro do PCB?

Otávio Velho: Somente no final de 1966 é que me tornei membro do $\mathrm{PCB}$, levado pela vontade de participar da resistência democrática. Na verdade o golpe militar foi decisivo nessa definição política. Fui militante do PCB durante quatro anos, de 1966 a 1970. E isso era paralelo ao meu mestrado no Museu Nacional. Em 1970 acontecem duas coisas importantes na minha vida: terminei o meu mestrado e recebi, através do PPGAS/MN, uma bolsa de pósgraduação da Fundação Ford. Assim, fui para a Inglaterra, para a Universidade de Manchester. A saída do país coincidiu com o fato de que nesse período as coisas começavam a esquentar politicamente para mim. Várias pessoas próximas foram presas por essa época. De certa maneira, sair do país foi uma opção ao mesmo tempo intelectual e política, porque realmente as coisas estavam ficando difíceis. Pouco tempo depois, quando já estava na Inglaterra, fui acusado de pertencer ao Partido Comunista e arrolado num inquérito policial militar. Na verdade foi muito bom estar fora do país nesse momento, porque outras pessoas, próximas a mim, que ficaram, foram presas e torturadas.

Sérgio Teixeira: Houve alguma deferência nessa questão política o fato de seu pai ser militar?

Otávio Velho: Logo depois do golpe militar fui chamado no inquérito a respeito do ISEB [Instituto Superior de Estudos Brasileiros], porque eu tinha assistido a alguns cursos lá e eles identificaram o meu nome. Quando fui prestar depoimento, o presidente do inquérito me reconheceu imediatamente pelo nome e disse ter me carregado no colo quando eu era criança. Coisas desse tipo aconteceram no início, quando o regime ainda era brando, mas, na época em que eu estava mais envolvido com o PCB, tive que me afastar da família porque se tornou muito difícil conviver com a pressão familiar e a militância política. Então, no processo mesmo em que fui arrolado, não houve nenhum envolvimento da minha família.

Bernardo Lewgoy: Lendo o seu memorial do concurso para professor titular do Museu Nacional, ficamos sabendo que além de você ter sido orientado por Peter Worsley, assistiu ao ultimo seminário de Max Gluckman. Qual a importância que esses fatos tiveram na sua maneira de pensar e na escolha do seu objeto de pesquisa? 
Otávio Velho: A ida para Manchester tem a ver com a minha formação anterior e com o meu orientador de mestrado, o professor Roberto Cardoso de Oliveira. Aliás, não só fui o primeiro mestre do Museu Nacional, mas também o primeiro orientando de Roberto. O Carlos Brandão brinca comigo dizendo que ele foi o primeiro. Mas ele foi o primeiro orientando do Roberto na UnB. O primeiro orientando dele fui eu realmente. Como discípulo do Florestan Fernandes, o Roberto pendia mais para o lado sociológico, em oposição ao culturalismo americano, enquanto as duas vertentes hegemônicas da época. Por isso ele tinha uma ligação forte com a antropologia social britânica. Assim, o caminho para Manchester teve a ver com isso e com o fato do departamento de Manchester na época ser um departamento de sociologia e antropologia. No entanto, as ligações do Roberto com Manchester eram, sobretudo, com o Brian Roberts, um professor americano que estava radicado na Inglaterra. E, entre as discussões iniciais sobre a minha ida e a minha chegada em Manchester, o departamento se cindiu em antropologia e sociologia. Assim, acabei ficando na sociologia pelo fato de que Brian Roberts ficou na sociologia, como também Peter Worsley. Mas era praticamente o mesmo departamento, funcionava no mesmo andar e a gente circulava pelos cursos e seminários indistintamente de um ou de outro.

Bernardo Lewgoy: Que professores de Manchester influenciaram mais na sua formação?

Otávio Velho: Frequentei na sociologia os cursos de Brian Roberts e de Peter Worsley, que foi meu orientador de tese. Na antropologia fui aluno de Max Gluckman e de Clyde Mitchell. Isso aconteceu num momento em que a chamada Escola de Manchester não estava mais no seu apogeu e Gluckman estava para se aposentar. Foi por isso que eu assisti ao último seminário que ele deu antes de se aposentar. No entanto, quando fui para Manchester não era propriamente para fazer doutorado. As bolsas que a Fundação Ford concedia na época - que permitiu que eu fosse para Inglaterra e o Gilberto para o Texas - eram apenas para fazer um ano de pós-graduação sem nenhuma referência a doutorado. Foi quando já estava lá que eles me convidaram para continuar e fazer o doutorado. A Fundação Ford concordou em estender a bolsa e acabei ficando lá para o doutorado. 
Carlos Steil: O fato de Manchester ser um departamento com certo viés marxista teve influência na sua formação?

Otávio Velho: Sim. Inclusive eu diria que me atrasei em termos de uma bibliografia propriamente antropológica porque o marxismo era na época significativo e importante tanto em Manchester quanto para mim pessoalmente. De fato o grupo de Manchester era considerado a esquerda da antropologia social britânica. Max Gluckman, por exemplo, era muito envolvido com as lutas políticas contra o apartheid na África do Sul. Peter Worsley era, ainda mais marcadamente, considerado de esquerda e com forte militância política. Então, digamos, juntou a fome com a vontade de comer. Isso me deu um certo apoio, inclusive político, porque, como mencionei anteriormente, logo que saí do país fui indiciado e passei a responder a um processo na Justiça Militar no Brasil, e fizeram parte da minha defesa depoimentos por escrito de Max Gluckman, de Clyde Mitchell, dizendo que eu era um bom moço. Em relação ao marxismo a passagem por Manchester e pela Europa - porque eu também circulei por Paris numa época que era logo depois de 1968 - foi muito importante para mim. No Brasil, eu estava bem enquadrado na estrutura partidária, do ponto de vista, inclusive, intelectual. Na Inglaterra eu me abri mais para o pensamento mais amplo de esquerda, para além do comunismo ortodoxo. Foi lá que li a obra do Trotski, que intelectualmente foi muito estimulante para mim. Acho Trotski genial como escritor e original como pensador. Enfim, essa referência forte ao marxismo dificultou que eu me aprofundasse tanto quanto eu gostaria hoje de ter me aprofundado na antropologia social britânica.

Carlos Steil: O que gostarias de ter aprofundado mais, lido mais no período em que estiveste na Inglaterra?

Otávio Velho: O próprio Gluckmann. Sem dúvida ele foi uma referência importante para mim, mas no livro Capitalismo autoritário e campesinato, que é a minha tese de doutorado, não faço referência a ele. Na verdade, a importância dele foi maior do que pode parecer e poderia ter sido maior ainda, se a minha fidelidade ao marxismo não tivesse sido tão forte. Mas é importante para as pessoas mais jovens entenderem que se tratava de uma fidelidade intelectual por causa da situação política. De alguma maneira, você era forçado a se posicionar em termos políticos como parte de sua trajetória intelectual. 
Havia, na época, uma ânsia existencial por compreender o que estava acontecendo com o país e um compromisso político que exigia um esforço intelectual de interpretação do Brasil. O que, de certa maneira, parece que diminuiu muito. Hoje, não estamos mais fazendo esses voos mais ambiciosos que buscam articular o trabalho acadêmico com a necessidade política e existencial de dar sentido às coisas.

Bernardo Lewgoy: Gostaria que você falasse de sua volta ao Brasil depois da tese. Qual seu horizonte em termos políticos, profissionais e intelectuais?

Otávio Velho: Fazendo uma ponte com o que estava sendo dito antes, a volta ao Brasil foi uma opção não tão óbvia. Como eu estava indiciado num processo na Justiça Militar brasileira, uma opção possível seria permanecer na Europa. Várias pessoas que estavam igualmente envolvidas em processos, algumas, inclusive, no mesmo processo em que eu estava, que era chamado: Processo dos Intelectuais, optaram pelo exílio. Realmente, a volta foi feita contra a opinião de pessoas próximas que achavam que era uma loucura voltar naquelas circunstâncias. Então, voltei respondendo a um processo. E sou muito grato ao Museu Nacional e ao Roberto Cardoso de Oliveira, particularmente, por terem me acolhido com toda a abertura e fraternidade em circunstâncias tão complicadas. Assim, pude continuar a trabalhar no museu mesmo respondendo ao processo na Justiça Militar, o que obrigou o próprio Roberto Cardoso e o Castro Faria a serem minhas testemunhas de defesa no processo. Eles compareceram na Segunda Auditoria da Marinha, onde corria o processo, e depuseram a meu favor, e como pessoas muito respeitadas. Castro Faria brandia o seu cachimbo na frente dos militares e dizia: "Aluno meu não tem tempo para fazer política." E acho que ele convenceu.

Carlos Steil: Qual era a sua situação no museu na época?

Otávio Velho: O Museu Nacional era, na época, um ambiente realmente muito fraterno e acolhedor, o que me levou a voltar para lá. Outros colegas estavam lá: Moacyr Palmeira, Lygia Sigaud. Não éramos, ainda, professores da universidade. E, como já sugeri em outras oportunidades, a pós-graduação em alguma medida se fez à revelia da estrutura universitária. No caso do PPGAS/MN, se não fosse o apoio da Fundação Ford, não teríamos conseguido 
sobreviver. Nesse começo, éramos pagos pela Fundação Ford. Depois entrou a Finep [Financiadora de Estudos e Projetos] e só mais tarde fomos sendo absorvidos pela universidade. Mas isso foi um processo lento. Outra coisa que aconteceu nessa época e que teve efeitos institucionais e pessoais foi a transferência do Roberto Cardoso para a UnB, em Brasília, para onde já tinha ido o Roque Laraia. Assim, o Roque e o Roberto, que eram duas referências importantíssimas para mim, foram para a UnB. Eles quiseram me levar, inclusive, mas preferi ficar no Rio. Com isso, ficamos um pouco órfãos no PPGAS/MN. O pai e o tio foram embora e nós tínhamos que nos virar. No início da formação do Programa, o Roberto DaMatta estava nos Estados Unidos, em Harvard, fazendo o seu doutorado. Ele desembarca no Rio, vindo do doutorado, sem nenhuma vocação administrativa, e é obrigado a assumir a coordenação do Programa, substituindo o Roberto Cardoso. Foi um período muito duro para o DaMatta, mas muito importante para o PPGAS/MN, porque foi justamente sob a coordenação dele que nos tornamos efetivamente professores da UFRJ [Universidade Federal do Rio de Janeiro].

\section{Carlos Steil: Quem foi o fundador do PPGAS/MN?}

Otávio Velho: Roberto Cardoso de Oliveira, juntamente David MayburyLewis, foram os fundadores do PPGAS/MN. Roberto Cardoso foi o primeiro coordenador e foi substituído pelo DaMatta. Depois sobrou para mim. Assim, fui o terceiro coordenador e o Gilberto, meu irmão, foi o quarto. Então, ainda muito jovens tivemos que assumir o encargo não só da rotina da administração, mas da própria constituição do PPGAS/MN. Na minha gestão, por exemplo, em 1978, é que se inicia o doutorado no programa. Enfim, estive envolvido desde o começo com a constituição do PPGAS/MN e com o início da pós-graduação em antropologia no Brasil. Esse duplo esforço, ao mesmo tempo intelectual e institucional, faz parte da minha trajetória. Quanto ao lado intelectual, nesse período já comecei a sentir um certo cansaço em relação ao tema do campesinato. Primeiro, porque eu sou mesmo dado a essas vontades de mudança, mas também porque passei a achar que o campo estava hiperpolitizado, e por isso, começou a se tornar desinteressante intelectualmente para mim, uma vez que a minha vontade sempre foi a de combinar o interesse político ou de responsabilidade social com o interesse intelectual. Quando as duas coisas não casam, complica. Foi isso que acabou me afastando um pouco do tema do campesinato. 
Bernardo Lewgoy: E o interesse pela religião, como entrou em sua trajetória intelectual?

Otávio Velho: O interesse pela religião veio da constatação de que de fato era um assunto importante que eu próprio havia negligenciado no meu trabalho anterior. No entanto, é importante mencionar que existe uma ponte entre o estudo do campesinato e o da religião na minha trajetória, que é o texto $O$ cativeiro da besta-fera, onde faço uma reanálise do meu material de campo sobre o campesinato sob uma ótica completamente diferente da anterior. Considero esse esforço uma contribuição minha para os colegas que estudavam o campesinato e que em geral eram muito pouco atentos à dimensão cultural, simbólica e religiosa das lutas no campo. Enfim, essa opção também faz parte do meu lado de militante, nesse caso, o de convencer os colegas de que a temática da religião é importante para as ciências sociais, particularmente no Brasil. Então, a partir daí eu passei a me interessar pela questão da religião. Mas, mesmo aí, nunca me tornei muito especialista. Como mencionei anteriormente, o meu interesse foi sempre o de juntar as coisas. Mesmo quando eu estudava o campesinato, o meu interesse era, ao mesmo tempo, a questão da fronteira, das frentes de expansão. Era o casamento dessas duas coisas. O que me mobilizava não era fazer uma sociologia ou antropologia da fronteira, mas, a partir da fronteira. Ou seja, o livro que resultou da minha tese é uma tentativa de pensar o Brasil a partir da fronteira, a partir da questão do campesinato e não um estudo especializado em campesinato. Sempre fui contra as compartimentações e isso é verdade também com relação à questão da religião. Eu nunca me tornei um especialista, por exemplo, em evangélicos, ou em pentecostais ou em Igreja Católica. Minha tentativa tem sido sempre mais genérica, de chamar a atenção para importância do campo, das fronteiras, da religião, etc., estimulando os alunos a fazerem trabalhos dentro desses campos.

Carlos Steil: Seria um reflexo do seu viés sociológico?

Otávio Velho: Talvez tenha a ver com esse viés sociológico, mas também com o meu background político. Acho que nunca consegui ser totalmente antropológico no sentido de ficar contente e satisfeito com o estudo localizado de campo. Eu sempre tive essa vontade de pensar questões mais amplas a partir de um lugar. É uma característica minha. 
Carlos Steil: Em dado momento, se torna público, na academia brasileira, que o Otávio Velho havia se convertido a uma igreja protestante. Você diria que o seu interesse pela religião se deu tanto no nível intelectual, temático, quanto pessoal?

Otávio Velho: De fato houve muita fantasia a respeito disso. Chegaram a me perguntar se eu havia "virado pastor". É muito interessante como isso deslanchou uma série de fantasias no nosso campo. Mas tinha um lado performático nisso, embora não se reduza a isso. Diria que, em alguma medida, tratava-se de uma maneira de demonstrar a importância da religião enquanto uma vivência pessoal. Por outro lado, a religião também entrou, naquele momento, como um sucedâneo da vivência do Partido Comunista. Na verdade, acho que a minha primeira igreja foi o Partido Comunista e a perda dessa referência - talvez seja difícil para um jovem hoje em dia pensar isso - deixou um sentimento de orfandade muito forte. Foi um momento em que já não era por motivos políticos e de repressão que eu já não podia mais militar, mas porque houve o desencanto com aquela forma de militância política. Havia uma sensação de orfandade que levou a uma conversão, se você quiser chamar assim, ou a uma volta à religião da infância, ao cristianismo. Mas também não consegui ficar por muito tempo como membro de uma igreja. Hoje me considero um cristão sem igreja. Como é que se diz Carlos? Você que sabe como é?

\section{Carlos Steil: Cristão de massa.}

Otávio Velho: Cristão de massa. Mas carregando, ao mesmo tempo, um paradoxo dentro de mim, que se expressa como uma convicção muito forte de que a antropologia tem um papel importante em chamar a atenção para a diversidade e a pluralidade de um cristianismo que não tem nada a ver com a vontade de converter o mundo, muito pelo contrário. Embora nos últimos anos não tenha tido nenhuma prática religiosa, considero que foi significativa pra mim aquela performance religiosa, que resultou em muitas fantasias que foram além do acontecimento em si.

Carlos Steil: Uma outra temática, sobre a qual gostaríamos de ouvir sua reflexão, é a das ONGs. Você foi presidente e membro de diretorias e conselhos de algumas ONGs no Rio de Janeiro. Qual a relação entre as ONGs, a academia e a produção intelectual na sua trajetória? 
Otávio Velho: No mundo das ONGs eu tive, sobretudo, uma relação forte com a Fase [Federação de Órgãos para Assistência Social e Educacional] e com o Iser [Instituto de Estudos da Religião]. No caso da Fase, o meu primeiro contato foi no campo. Eu tinha duas orientandas que estavam fazendo pesquisas na região de Santarém e a entrada delas no campo de Santarém se fez por meio da Fase, que, naquela época, tinha um escritório em Santarém. Acabei indo a Santarém e conhecendo o pessoal da Fase de lá. Foi a partir daí que comecei a estabelecer uma relação com a Fase. Mais tarde cheguei a ser presidente do conselho da Fase. Os meus dois ex-alunos, que me levaram a conhecer a Fase são dirigentes da Fase, até hoje. São o Jorge Eduardo Durão e a Maria Emília Pacheco.

Carlos Steil: Seria importante dizer o que é a Fase. Possivelmente alguns dos nossos leitores não a conheçam.

Otávio Velho: A Fase é possivelmente a primeira ONG do país. Teve uma origem religiosa, católica, e depois se tornou um lugar de refúgio e de trabalho para pessoas de esquerda no período do regime militar especialmente. A sede é no Rio, mas ela tem uma abrangência nacional e uma importante relação com movimentos sociais. Minha experiência com a Fase foi de certa maneira de uma "antropologia aplicada". Por meio da Fase eu tive a oportunidade de conhecer alguns lugares no interior do Brasil e de travar um certo tipo de discussão que foi importante pra mim. Já com o Iser, que também está dentro desse universo das ONGs, acabei tendo um envolvimento devido o meu interesse pela temática da religião e o fato de um colega do Museu Nacional, o Rubem César Fernandes, ter se tornado um dirigente importante do Iser. A relação com o Iser permanece até hoje através da revista Religião e Sociedade. E esse é caso interessante para se pensar a relação das ONGs com a academia. Às vezes imaginamos as $\mathrm{ONGs}$ como mundo à parte, no entanto a revista Religião e Sociedade parece desfazer essa ideia, uma vez que, mesmo sendo publicada por uma ONG, é uma referência importante em termos de ciências sociais na temática da religião. Enfim, o Iser tem um lugar importante na história do estudo da religião no Brasil. Também fui presidente do conselho do Iser. Assumi esses cargos tanto no Iser quanto na Fase como uma maneira de dar apoio a quem estava trabalhando no dia a dia dessas instituições. Hoje minha relação com o Iser é muito pouca, apenas com a revista, e com a Fase, é só indireta e relativamente pequena. 
Carlos Steil: Você poderia falar um pouco de sua relação com as associações acadêmicas como a SBPC [Sociedade Brasileira para o Progresso da Ciência], a ABA [Associação Brasileira de Antropologia] e a Anpocs [Associação Nacional de Pós-Graduação e Pesquisa em Ciências Sociais], nas quais você teve um importante papel como militante e dirigente?

Otávio Velho: Acho importante pensar nas articulações que a academia pode estabelecer com instituições que estão na sociedade civil ou que a tangenciam. Diria que fez parte da trajetória da minha geração a criação das instituições científicas no país e o trabalho organizacional. No caso da ABA, por exemplo, tive um certo papel na sua refundação, em 1978. Em relação à Anpocs, sou um dos seus fundadores e fui membro das três primeiras diretorias e o seu quarto presidente, o primeiro antropólogo. Já a SBPC tem sido um espaço privilegiado de militância para mim desde os anos de 1970 e continuo ligado a ela, tendo sido membro do seu conselho, da sua diretoria e atualmente sou vice-presidente da SBPC, num segundo mandato. Esse tem sido realmente o trabalho mais orgânico que desenvolvi ao longo da minha trajetória e que tem sido uma referência muito boa, que cultivo até hoje, especialmente porque permite o contato constante com colegas de outras áreas que não a das ciências sociais. Construí, nesse espaço, amizades sólidas e importantes com pessoas de outras áreas. Sempre busquei essa transversalidade por meio do relacionamento com outras áreas. Hoje estou aposentado e não tenho mais uma rotina na universidade, embora continue participando de seminários, congressos, bancas e escrevendo. Então, minha rotina hoje está ligada à minha função na SBPC, que é sempre muito prazerosa e produtiva e que me permite conhecer lugares e pessoas em todo o Brasil.

Carlos Steil: Na sua trajetória você assumiu posições políticas que te deram alguma projeção. Entre elas, sua defesa da monarquia no Brasil, no plebiscito pela escolha do regime político no país. Hoje, você tem tomado posições claras e públicas de apoio ao governo Lula. Como estas posições se articulam em sua trajetória de vida?

Otávio Velho: É importante não dar uma ideia evolutiva dessa trajetória: começou monarquista e acabou petista. De fato a minha fase da monarquia foi provocada pelo plebiscito para escolha da forma de governo ou de regime. 
$\mathrm{Na}$ verdade, foi uma coisa episódica. E, antes de monarquista, havia sido comunista. Mas nunca fui petista. O que acontece é que estou convencido que o governo Lula marca uma transição importante no país e que algo realmente novo está acontecendo. Por isso, dou muito apoio ao governo, apesar de ter divergências em vários aspectos da sua política. Já a monarquia, acho que foi mais uma performance que queria chamar a atenção para uma certa naturalização da república e da democracia. Um discurso político fácil de viés evolucionista, que apenas ratificava a ideia de que todos éramos republicanos e democratas, me incomodava. Então, ao defender a monarquia queria mostrar que optar pela república era alguma coisa séria que deveria levar as pessoas a pensar. Enfim, foi uma performance que visava sacudir um discurso político fácil. E, no meu último livro, Mais realistas do que o rei, que é uma coletânea de artigos meus, resolvi reproduzir um dos textos da época, para que o leitor tivesse um pouco a ideia do raciocínio envolvido nessa questão da monarquia. Um argumento forte nesse texto é o de que a política não é só um terreno do cálculo estratégico, mas é também um terreno das identificações, dos símbolos e das representações. Eu achava que o não reconhecimento dessa dimensão da política estava produzindo uma certa patologia da vida política. Por outro lado, eu acreditava que esse reconhecimento poderia se dar por meio da figura do monarca, o que tornaria a monarquia algo saudável do ponto de vista da vida política. Acho sinceramente que isso foi só uma performance e essa questão não se coloca mais para mim hoje.

Carlos Steil: Como essa sua ideia da monarquia se articula com o governo Lula hoje?

Otávio Velho: Eu achava que a figura do monarca tem um enraizamento popular no Brasil e que ter um rei de fato poderia ser uma maneira de articular a população com o regime político. Minha avaliação era a de que a política era um terreno da elite no Brasil e que era preciso torná-la popular. Então, o apoio à monarquia para mim não tinha um viés de elite, mas, mas ao contrário, de massa, como uma maneira de possibilitar realmente a identificação e a associação do povo com as questões políticas. Hoje, acho que o Lula conseguiu fazer essa associação, substituindo perfeitamente bem o monarca. Eu dizia, ainda a propósito da monarquia, que era uma performance e que é uma coisa do passado. É coisa do passado, mas que talvez tenha mais a ver com o presente 
do que fica sugerido com o que eu disse antes. Talvez não seja à toa que eu tenha intitulado o meu último livro Mais realistas do que o rei. Enfim, o que eu queria no fundo era, como eu dizia, ser testemunha, para mim mesmo, inclusive, de que a vida social é um jogo, em que o compromisso consiste menos em conformar-se à opinião média ou ao pertencimento a uma facção e mais em aceitar representar um papel cambiante, em ocupar um lócus dramático, performático, sem o qual o jogo se empobreceria. Nesse sentido, uma das

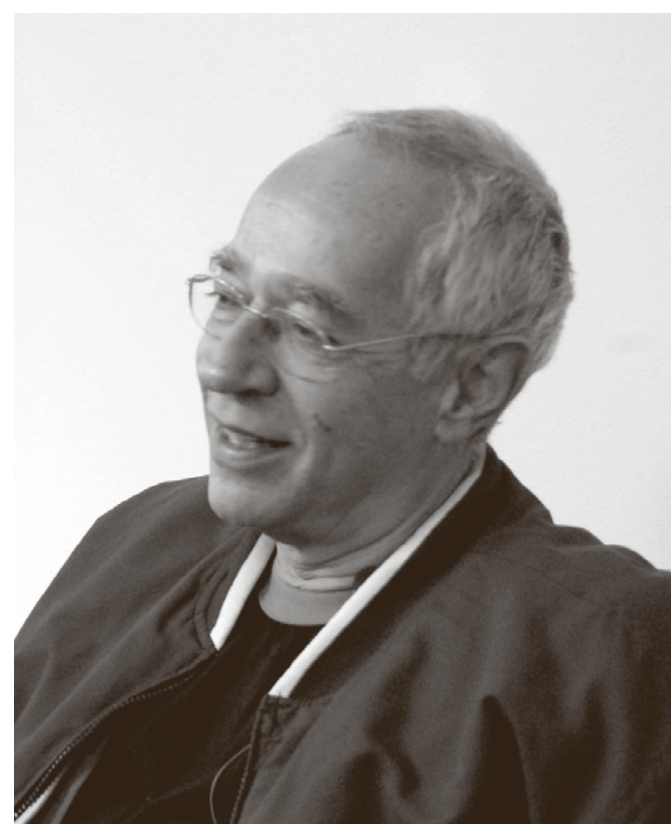
coisas que estava querendo performatizar era a crítica a um certo "espírito de modernidade", que consiste em um receituário-padrão que torna a modernidade um pouco caricata. Por isso, essa ideia de mais realistas do que o rei quer questionar o fato de que na Europa você pode pensar numa monarquia moderna, enquanto no Brasil isso é impensável. Esse impensável no Brasil que é uma espécie de "mais realista do que o rei". Esse espírito acho que de alguma maneira ainda permanece, o que torna essa discussão atual, que eu chamei de "mais realistas do que o rei". Uma certa tendência a reificar certas formas que considero importante de sacudir. Ora para um lado, ora para o outro eu gosto de sacudir esse espírito de modernidade um pouco fácil, um pouco reificado, um pouco falso.

Sérgio Teixeira: Ontem [na conferência de comemoração dos 35 anos do Programa de Pós-Graduação em Antropologia Social da UFRGS] você levantou uma questão do crescimento da pós graduação "com pés de barro", porque o ensino fundamental é deficiente. Uma das formas de enfrentar essa questão se expressa na política de cotas na universidade. Eu queria ouvi-lo sobre isso.

Horizontes Antropológicos, Porto Alegre, ano 16, n. 34, p. 481-506, jul./dez. 2010 
Otávio Velho: Acho que realmente existe essa questão dos "pés de barro" e que a comunidade cientifica em geral está mais consciente disso do que os cientistas sociais em particular. Estamos, nesse aspecto, um pouco atrasados em relação a outras áreas do conhecimento. E precisamos pensar como as ciências sociais podem contribuir para uma reformulação da educação no Brasil. Para ficarmos no campo da antropologia, eu acho que existem muitos aspectos, mas gostaria de chamar atenção para um apenas. A antropologia no Brasil desenvolveu-se enormemente nos últimos anos e hoje ela rivaliza com as principais antropologias do mundo. Ao mesmo tempo, acho que existe um certo "pé de barro" que se evidencia no tipo de enraizamento e no efeito que esse desenvolvimento teve na sociedade brasileira. Tendo a achar que o efeito é pequeno. Mas em que aspecto cabe-nos contribuir? Responderia, em termos sintéticos, que é na constituição de uma sociedade intercultural. Diria que o século XXI será o século da interculturalidade, porque essa questão está estourando por todos os lados e não só no Terceiro Mundo, mas sobretudo na Europa e nos Estados Unidos. Alguns colegas chamariam de multicultural, eu prefiro o intercultural.

Carlos Steil: Como o Brasil está lidando com essa questão da interculturalidade?

Otávio Velho: Acho que no Brasil há um certo despreparo, inclusive das nossas próprias elites, em relação à vivência de uma situação intercultural. Por isso mesmo, a antropologia poderia dar uma contribuição nessa direção. Na minha opinião, há no Brasil uma certa ideologia da unidade nacional que dificulta a percepção da diversidade. E, no campo das relações raciais, isso se manifesta como uma ideologia da mestiçagem. Na verdade, não se trata de ignorar ou de negar o fato da mestiçagem, que é importante, aliás, não só no Brasil, mas de se discutir o seu efeito enquanto ideologia. No momento em que você afirma que todos somos mestiços você acaba negando o outro, já que todos somos iguais e mestiços. Essa perspectiva acaba dificultando assumir a diversidade e a questão do outro, que são questões centrais para a antropologia. A meu ver - apesar da sua dramaticidade - as cotas raciais estão no campo da política prática e são um instrumento entre outros possíveis para se chamar a atenção para a questão da diversidade. O risco que corremos com o debate das cotas hoje no Brasil é o de cairmos num certo binarismo, perdendo 
inclusive a dimensão da diversidade. Escrevi recentemente um artigo que abria com uma epígrafe de um filósofo africano que afirmava que o antídoto está contido no veneno. Ou seja, o que torna difícil a questão das cotas raciais é você, de alguma maneira, ser obrigado a entrar na linguagem daquilo que você está querendo combater, ou seja, a ideia de raça. É evidente que não estamos querendo aqui propugnar a existência das raças, enquanto fato biológico, mas apenas identificando-as como fato social. Resumindo, diria que sou a favor das cotas raciais enquanto um instrumento capaz de produzir não apenas um efeito prático, mas também simbólico, na constituição de uma sociedade que realmente se assuma como intercultural.

Bernardo Lewgoy: O debate das cotas raciais está aí e penso que todo mundo tem obrigação de se posicionar em relação a um caso, embora isso possa gerar uma divisão binária. Isso faz com pessoas com uma posição pró-cota pareça identificada com o outro lado e vice-versa. Meu interesse aqui é que você desenvolvesse um pouco mais a ideia do que está causando tanto incômodo no interior do próprio campo das ciências sociais. A minha pergunta é se esse incômodo não estaria relacionado com o fato da genética estar assumindo um papel de legitimadora da cultura?

Otávio Velho: Bom, deixa-me ver como é que eu consigo juntar essas coisas. Quanto à necessidade de se posicionar, acho que a questão está posta com tal dramaticidade que eu não vejo porque não fazê-lo, sobretudo quem trabalha e vive na universidade. Para mim mesmo, foi inesperado que essa questão fosse capaz de criar uma polêmica de grande porte. Pessoalmente, não acho que se posicionar quanto a isso é uma questão moral. Precisamos, sim, nos posicionar porque estamos na universidade e essa questão está posta aí. Quanto ao papel da genética, isso tem a ver com a minha militância, inclusive, na SBPC. Na verdade, é sempre meio paradoxal, porque, por um lado, eu estimulo e quero a relação com as outras áreas, mas, por outro, percebo as dificuldades e os riscos de se deixar envolver por um pensamento que tende muitas vezes a assumir uma visão essencialista. Para usar a linguagem "latouriana”, a questão é das condições de simetria das relações com as outras áreas. E, na medida em que a genética é a ideologia da nossa época, isso de fato coloca dificuldades para nós. Do ponto de vista da questão racial no Brasil para mim é claro que não estamos falando de genética, mas de questões de inserção 
social e de identidades coletivas. Vejo, às vezes, com certa tristeza, colegas cientistas sociais se utilizando de argumentos genéticos para demonstrar que raça não existe, quando evidentemente essa é uma falsa questão. Também não acho que a cota racial vai resolver todos os problemas da educação, mas penso que pode ter efeito sobre essa área, na medida em que as cotas podem contribuir para o surgimento de um grupo de profissionais, considerados racialmente negros, inclusive com presença em salas de aula. Outro dia, estava numa reunião em que uma pessoa negra falava que ela nunca havia tido um professor negro e da dificuldade das pessoas negras terem a oportunidade de se identificarem com um negro como professor. Então, mesmo que não seja possível atingir a massa com a política de cotas, ela pode ser um recurso importante para se criar modelos, paradigmas, ícones e referências para pessoas que são socialmente identificadas como negros. Nós acabamos naturalizando a ausência dos negros no espaço acadêmico e universitário. E essa é uma questão que precisamos enfrentar. Os estrangeiros, quando vêm aqui, identificam isso muito rapidamente. Certamente as questões da educação são mais amplas e de maneira alguma estou reduzindo-as à questão racial, mas creio que essa questão acabou se tornando um ponto nodal para pensarmos e agirmos na sociedade brasileira.

Bernardo Lewgoy: Mas isso não implicaria ter que fazer uma falsa opção entre o ensino superior e o ensino fundamental?

Otávio Velho: De maneira alguma. Não concordo com o argumento que não precisamos enfrentar essa questão no plano da universidade, porque primeiro devemos resolver o problema do ensino fundamental. Ao contrário, penso que se trata de uma questão sistêmica, que precisa ser enfrentada sistemicamente, sem dar prioridade a uma coisa ou a outra.

Bernardo Lewgoy: Na última reunião da Anpocs, você fez uma conferência sobre a antropologia e o Brasil de hoje, em que você destacava que antigamente a antropologia teve uma participação importante no desenho e na reflexão sobre um projeto nacional, mas agora essa participação precisa ser repensada, uma vez que a diversidade transborda esse projeto nacional. Estou correto na interpretação do que você falou na ocasião? 
Otávio Velho: É isso mesmo. Penso que estamos diante do desafio de uma refundação do nosso projeto nacional que terá como base muito mais a ideia de diversidade do que da unidade. Ou seja, precisamos imergir na diversidade para ver que unidade é possível retirar daí, uma vez que esta não está dada a priori. Por exemplo, em relação ao reconhecimento das terras indígenas, estamos dramaticamente diante da diversidade. No entanto, essa questão tem causado pouca polêmica entre os antropólogos, que têm se posicionado quase que unanimemente na defesa dos territórios indígenas, contra a opinião dos paranoicos da segurança nacional que acham que a unidade nacional fica comprometida com esse tipo de reconhecimento. No fundo, penso que a questão indígena, assim como a das cotas raciais, está ligada à questão da diversidade. Ou seja, já não se trata mais de um projeto a ser elaborado pelos intelectuais, mas de um projeto que está aí, independente de nossas posições como antropólogos. Trata-se, enfim, de um momento de transição entre um projeto de uma unidade nacional naturalizada e um projeto de uma unidade nacional a ser constituída, a partir do reconhecimento da diversidade. Uma diversidade que não se apresenta como um empecilho, uma dificuldade, mas como uma riqueza que deve ser reconhecida enquanto tal. Por outro lado, os antropólogos estão em posição privilegiada para enfrentar essa questão, não em relação à questão indígena no país, mas como uma questão global que nos aproxima de outros países, uma vez que, apesar das nossas especificidades, essa é uma questão mundial.

Bernardo Lewgoy: Uma questão que gostaria de propor era sobre a influência do pós-colonialismo no teu pensamento e sua relação com autores latino-americanos como Aníbal Quijano, Edgar Lander e outros.

Otávio Velho: De um modo geral, diria que outra questão que está colocada fortemente no Brasil hoje é a sua inserção na América Latina e, de certa maneira, remando contra a maré do eurocentrismo, o qual nos tem direcionado para o Primeiro Mundo e contribuído para criar uma espécie de ignorância em relação aos nossos vizinhos. A propósito, quando estive em Porto Alegre, há mais de 30 anos atrás, para avaliação do Programa de Pós-Graduação em Antropologia Social da UFRGS, eu falava que a vocação natural do programa, sua especificidade, seria a inserção regional no Cone Sul, tomada nesse sentido internacional. 
Sérgio Teixeira: Uma outra questão que gostaria de colocar é sobre a tua participação em comitês de avaliação dos cursos de pós-graduação e qual o papel que o sistema de avaliação teve de um modo geral na qualificação da pós-graduação no Brasil.

Otávio Velho: Penso que a antropologia no Brasil se desenvolveu enormemente e tem hoje uma produção muita significativa, diversificada e pioneira em alguns campos. Fomos pioneiros em fazer uma antropologia de nós mesmos, da nossa sociedade e isso é muito relevante. Por outro lado, chegamos a uma homogeneidade muito grande, para o bem ou para o mal. Por exemplo, a minha ideia de que cada programa deveria descobrir a sua vocação tem sido, de certa maneira, frustrada, porque os programas se tornaram muito parecidos entre si. Mas, se isso é uma certa vantagem, na medida em que facilita a comunicação e o diálogo, por outro perdemos a riqueza da diversidade. E gostaria de continuar insistindo que cada programa deveria procurar a sua vocação, o seu caminho e ousar um pouco mais. Nos anos 1970, foi gestada uma certa fórmula que nos conduziu a um nível ótimo de relação, a qual tem sido reproduzida até hoje, mas eu gostaria que fizéssemos novos experimentos, que tentássemos pensar coisas novas. Isso seria saudável para a antropologia brasileira, como um desdobramento natural a partir do que ela já alcançou até agora que, certamente, tem sido excepcional e muito relevante.

Bernardo Lewgoy: Mudando um pouco o eixo da entrevista, seria possível você falar um pouco sobre os momentos de inflexão que foram fundamentais na tua trajetória intelectual? Sabemos que ela é formada por muitos artigos, o que revela um certo pendor positivo e muito saudável para o ensaísmo. Ao mesmo tempo, vê-se que em alguns livros esses artigos são repensados em um outro patamar, como no Cativeiro da besta-fera e no Mais realistas do que o rei. Enfim, queria entender como se deu esse processo na sua própria rotina de trabalho intelectual.

Otávio Velho: Diria que, embora eu tenha um certo lado reflexivo, também tenho esse lado performático e de engajamento social que torna difícil julgar o que estou fazendo no momento, o que fica mais a critério dos outros. Como tenho uma produção bastante diversificada, tenho passado por várias fases. Por outro lado, surpreendo-me muitas vezes com a apropriação que é 
feita do meu trabalho. Por exemplo, para mim Frentes de expansão e estrutura agrária era uma obra do início da minha trajetória, que estava datada. Mas ultimamente, através de um certo retorno que eu tenho feito à Amazônia, vejo que para certas pessoas e certos grupos essa bibliografia continua sendo importante e não só em termos históricos, como algo que passou. Nesse sentido, há dois anos atrás eu tive uma experiência muito gratificante, que foi um seminário comemorativo dos 40 anos que eu comecei a fazer pesquisa no Tocantins paraense, organizado pela Universidade Federal do Pará. A primeira metade do seminário foi em Belém e a segunda em Marabá, que era a cidade-referência na região onde havia feito os meus primeiros trabalhos. Aí, de repente, descubro que as pessoas estão usando esses trabalhos e que isso ainda tem algum significado. E, então, compreendo que essas coisas ainda tem um significado para mim, mesmo que seja metaforicamente, como a ideia de fronteira que, de alguma maneira, tem um significado, independentemente da fronteira física imediata. Por isso, talvez, tenha certa dificuldade em reler as coisas que fiz e pensar em termos evolutivos, considerando as coisas que estou fazendo hoje mais importantes do que as que fiz no passado.

Bernardo Lewgoy: Se me permites uma observação, gostaria de chamar a atenção para o subtítulo "ocidentalismo" que está no livro Mais realistas do que o rei. Esse subtítulo não chega a ser justificado ao longo do livro.

Otávio Velho: É que o subtítulo foi colocado no final e talvez eu estivesse apontando mais para coisas que estou pensando agora do que propriamente o que está contido nesse livro. Ou talvez, já esteja no livro, mas com outra nomenclatura ou outros conceitos. Creio que a minha tese de doutorado sobre o capitalismo autoritário e o campesinato faz parte do conjunto das tentativas de pensar o Brasil dos anos 1970 e tem um certo valor dentro desse conjunto de obras da época. Nesse sentido, o texto do Cativeiro da besta-fera é importante como ponte entre a questão rural e a questão da religião. As minhas inquietações hoje continuam sendo muitas, mas uma coisa central e permanente tem sido a tentativa de criar pontes e diálogos e evitar a especialização excessiva. Escrevi um texto, que até agora só foi publicado numa revista eletrônica [Epistrophê: do duplo vínculo às antinomias e de volta. Rever, PUC/SP, ano 7, p. 123-144, setembro de 2007], em que tento pensar a religião como um modo de conhecimento e de diálogo possível com a antropologia, tendo a obra do 
Gregory Bateson como uma referência fundamental. Então, uma das provocações que faço à antropologia é que leve a sério que o teólogo ou o praticante da religião pode eventualmente estar produzindo conhecimento. E isso tem a ver com o fato de que antropologia tem que tratar o outro não apenas como objeto, mas também como parceiro.

Cornelia Eckert: O que você diria hoje para os novos antropólogos?

Otávio Velho: A partir da ideia de diálogo que mencionei, gostaria mais de ouvi-los do que de falar. Para dizer algo importante, diria que, na aposentadoria, não sinto falta das reuniões de departamento, mas da relação com os alunos eu sinto falta. Acho que realmente ela é muito enriquecedora e que é exatamente dessa interlocução, desse dialogo, que é muito vivificador para nós, que sinto falta. Uma coisa que nos caracterizou até agora e que, talvez, precise ser repensada, é o liberalismo na nossa relação com os alunos. Por exemplo, o sujeito propõe um tema de tese e, sem uma discussão mais aprofundada, aceita-se simplesmente. Enfim, penso que, no campo científico hoje, não bastam ao pesquisador as suas qualidades intelectuais, mas também tem que ter capacidade de liderança e de agregação. Nesse sentido, diria que as ciências sociais e a antropologia em particular precisa se acostumar com a ideia de projetos coletivos, o que acaba exigindo que o aluno não faça o que lhe der na telha, mas, de alguma maneira, faça alguma coisa articulada com um projeto maior, o que já é banal e usual em outras áreas. Mas isso já seria assunto para uma outra conversa.

Entrevista: Sérgio Alves Teixeira, Bernardo Lewgoy, Carlos Alberto Steil

e Cornelia Eckert

Câmera: Rafael Devos, Patrick da Silva Barcelos e Anelise Gutterres

Som: Stephanie Ferreira Bexiga e Priscila Farfan Barroso Fotografia: Stéphanie Ferreira Bexiga, Luciana Tubello Caldas, Ana Luiza Carvalho da Rocha e Cornelia Eckert Transcrição: Karin dal Bauken, Keista Dorigoni, Luciano Von der Goltz Vianna, Érica Pastori e Rodrigo Toniol Edição: Carlos Alberto Steil 